CLINICAL STUDY

\title{
Iodine levels and thyroid hormones in healthy pregnant women and birth weight of their offspring
}

\author{
M Alvarez-Pedrerol ${ }^{1,2}$, M Guxens ${ }^{1,2}$, M Mendez $^{1}$, Y Canet $^{3}$, R Martorell ${ }^{4}$, M Espada ${ }^{5}$, E Plana ${ }^{1,2}$, M Rebagliato ${ }^{2,6}$ \\ and J Sunyer ${ }^{1,7,8}$ \\ ${ }^{1}$ Centre for Research in Environmental Epidemiology-IMIM, C. Doctor Aiguader 88, 08003 Barcelona, Spain, ${ }^{2}$ CIBER Epidemiologia y Salud Pública \\ (CIBERESP), Doctor Aiguader 88, 08003 Barcelona, Spain, ${ }^{3}$ Hospital Parc Taulí, 08208 Sabadell, Barcelona, Spain, ${ }^{4}$ Hospital de Terrassa Ctra. \\ Torrebonica s/n. 08227 Terrassa, Spain, ${ }^{5}$ Laboratorio Normativo de Salud Pública, Departamento de Sanidad Gobierno Vasco, Bilbao, Spain, ${ }^{6}$ Miguel \\ Hernandez University, Elche, Spain, ${ }^{7}$ Municipal Institute of Medical Research (IMIM-Hospital del Mar) and ${ }^{8}$ Pompeu Fabra University, Doctor Aiguader \\ 88, 08003 Barcelona, Spain \\ (Correspondence should be addressed to M Alvarez-Pedrerol; Email: malvarez@creal.cat)
}

\begin{abstract}
Introduction: The fetus is most vulnerable to severe iodine deficiency and hypothyroidism during pregnancy. The effects of mild iodine deficiency and subclinical hypothyroidism are poorly known. The present study assesses the association between thyroid hormones (TH)s and urinary iodine concentration (UIC) in healthy pregnant women and the birth weight of their children.

Methods: About 657 pregnant women were recruited in Sabadell and followed until delivery. The association between THs during the first trimester, UIC during the first and third trimesters, and birth weight was studied in 557, 251, and 528 mother-newborn pairs respectively, using linear and logistic regression models adjusted for potential confounders. Only 239 women had all the data available (thyroid function and UIC at the first and third trimesters). Six percent of newborns were classified as small for gestational age (SGA).

Results: The median UIC was 95 and $104 \mu \mathrm{g} / \mathrm{l}$ during the first and third trimesters respectively. Women with the third trimester UICs between 100 and $149 \mu \mathrm{g} / \mathrm{l}$ had lower risk of having an SGA newborn than women with UICs below $50 \mu \mathrm{g} / \mathrm{l}$ (adjusted OR (95\%CI): $0.15(0.03-0.76)$. There was no significant reduction in SGA among mothers with higher UICs. Lower free thyroxine and higher TSH levels during the first trimester were not associated with birth weight or SGA. Nevertheless, the analyses were repeated including only those women with all the data available, and high TSH levels became statistically significantly associated with lower birth weight and higher risk of SGA.

Conclusions: The present study suggests that iodine status during pregnancy may be related to prenatal growth in healthy women.
\end{abstract}

European Journal of Endocrinology $160423-429$

\section{Introduction}

Iodine is required for the synthesis of thyroid hormones (TH)s, which are important for the development of the fetus, especially for the maturation of the $\mathrm{CN}(1)$. The fetus is dependent on the mother's THs in the early stages of pregnancy, so it is important that pregnant women have adequate $\mathrm{TH}$ and iodine levels (2). Iodine deficiency and hypothyroidism during pregnancy have long been known to be associated with neurological deficits and mental retardation (3-5); however, there is also evidence for an increased risk of adverse effects on obstetrical outcomes such as preeclampsia or placental abruption, and negative effects on the offspring such as preterm birth, fetal death, or low birth weight (6-10). Most of the studies that have assessed the effects on reproductive or perinatal outcomes have compared hypothyroid pregnant women to euthyroid pregnant women $(6-8,11-13)$, pregnant women living in an iodine-deficient area to pregnant women living in an iodine-sufficient area (9), or iodine-supplemented pregnant women to non-iodine-supplemented pregnant women $(14,15)$.

The present study was undertaken to assess the association between $\mathrm{TH}$ and urinary iodine concentration (UIC) in healthy pregnant women from an area with an unknown iodine status and the birth weight of their children. The objective was to evaluate whether weight at birth may be affected by free thyroxine $\left(\mathrm{T}_{4}\right)$ and thyrotropin (TSH) concentrations in the lower and upper limit of the population range respectively as well as the consequences of an iodine deficiency.

\section{Methods}

A population-based birth cohort was established in the city of Sabadell (Catalonia, Spain). Between July 2004 
and July 2006, 657 pregnant women who visited the public health center of Sabadell for an ultrasound in the first trimester were recruited. Information on education, socioeconomic background, demographic factors, marital status, maternal health and obstetric history, parity, medication use, alcohol and smoking habits during pregnancy, anthropometric measures, and dietary intake were obtained through questionnaires administered during the first and third trimesters of pregnancy. Thyroid function (free $\mathrm{T}_{4}$ and $\mathrm{TSH}$ ) was assessed during the first trimester of pregnancy, and UIC was measured at the first and third trimesters. A total of 619 (94\%) women were followed until delivery, and anthropometric measures, sex, and gestational age of their children were obtained by specially trained staff and from clinical records. A woman who had a TSH concentration of $126 \mathrm{mU} / \mathrm{l}$ and a free $\mathrm{T}_{4}$ concentration of $0.016 \mathrm{ng} / \mathrm{dl}$ $(n=1)$, those women who had a thyroid disorder diagnosed $(n=36)$, a woman with a child born with some malformations $(n=1)$, and women whose children had been born before 34 weeks of gestation $(n=6)$ were excluded. In addition, some women had missing data and were also not included in some of the three different analyses (i) free $\mathrm{T}_{4}$ and TSH versus birth weight, ii) UIC at the first trimester versus birth weight, and iii) UIC at the third trimester versus birth weight). Therefore, 563 mother-newborn pairs $(86 \%)$ were included in the first analysis, 257 mother-newborn pairs (39\%) in the second analysis, and 534 mother-newborn pairs $(81 \%)$ in the third analysis. More than half of the recruited women had missing data to assess the association between UIC at the first trimester of pregnancy and birth weight, given that we begin to collect urine samples for iodine quantification at half recruitment. Complete data (UIC at the first and third trimesters, thyroid function, birth weight, and covariables) were available in 245 women. Informed consent was signed and the study was approved by the ethics committee of the Institut Municipal d'Investigació Mèdica, Barcelona.

\section{Thyroid hormones and UICs measurement}

Thyroid function was assessed during the first trimester of pregnancy by measuring concentrations of TSH and free $\mathrm{T}_{4}$ in serum samples (Normative Public Health Laboratory of Bilbao, Basque Country, Spain) using a solid-phase, time-resolved sandwich fluoroimmunoassay (AutoDELFIA, PerkinElmer Life and Analytical Sciences, Wallac Oy, Turku, Finland) using a lanthanide metal Europium (Eu) label. The between-assay coefficients of variation (CVs) at three levels of hormone concentration were $3.0,3.1$, and $2.6 \%$ for low, medium, and high concentrations of TSH respectively, and $6.1,4.1$, and 4.0 for free $\mathrm{T}_{4}$. The intra-assay CVs were $7.7,2.1$, and $1.7 \%$ for TSH, and $3.7,3.0$, and $3.3 \%$ for free $\mathrm{T}_{4}$. UICs were measured in single spot urine samples in a total of 303 and 600 pregnant women during the first and third trimesters of pregnancy respectively, using paired-ion reversed-phase high-performance liquid chromatography with electrochemical detection and a silver working electrode. Samples were stored at $-20{ }^{\circ} \mathrm{C}$ prior to the analyses.

\section{Birth weight}

Birth weight was studied both as a continuous variable and as a dichotomous variable based on small size (weight) for gestational age. Small for gestational age (SGA) was used as a definition for intrauterine growth restriction to identify those children whose birth weight was below the 10th percentile of the distribution for the corresponding gestational age according to Spanish reference tables from Carrascosa et al. (16). Additionally, a new definition for growth restriction based on failing to achieve their growth potential (17) was also used to better distinguish intrauterine growth restriction from constitutionally small infants (i.e., with parents of small stature). Fractional polynomial model was used to predict birth weight taking into account maternal and newborn characteristics (gestational age as inverse of square, sex, interaction of sex and gestational age, maternal age height and weight, and parity). We developed an adjusted SGA variable (SGAadj), which considered as SGA infants only those newborns classified as small in the two definitions $(n=32)$, and excluded infants classified as SGA using the Spanish reference tables, but whose birth weight exceeded the 10th percentile of predicted values $(n=6)$. Therefore, 557, 251, and 528 mother-newborn pairs were finally included in the subsequent analysis to assess the effects of thyroid function, UIC at the first trimester, and UIC at the third trimester respectively, and only 239 women had complete data (all measurements). Children classified as large for gestational age (LGA) $(n=59)$ were included in the analysis; however, the analyses were repeated excluding these newborns and results were compared.

\section{Statistical analysis}

The population was classified into five groups according to their UICs: i) $<50 \mu \mathrm{g} / \mathrm{l}$, ii) $50-100 \mu \mathrm{g} / \mathrm{l}$, iii) $100-$ $150 \mu \mathrm{g} / \mathrm{l}$, iv) $150-249 \mu \mathrm{g} / \mathrm{l}$, and v) $>250 \mu \mathrm{g} / \mathrm{l}$ based on the WHO classification (18) in order to examine the linearity of the relationship between UIC and the outcomes. Free $\mathrm{T}_{4}$ and TSH were categorized using the 10th and 90th percentiles respectively. The association between free $\mathrm{T}_{4}$, TSH, and UIC (as categorical variables) and birth weight (as the dichotomous and continuous variable) was evaluated using logistic and linear regression. Models were adjusted for time of day, gestational age, and season at sampling, mother's smoking habits, mother's age, weight and height, infant's sex, and nulliparity (when using adjusted SGA as the outcome). Models using birth weight as a continuous outcome were also adjusted for gestational 
Table 1 Thyroid hormones and urinary iodine concentrations (UIC) in pregnant women.

\begin{tabular}{|c|c|c|c|c|}
\hline & \multirow[b]{2}{*}{$n$} & \multicolumn{3}{|c|}{ Percentiles } \\
\hline & & 25th & 50th & 75th \\
\hline \multicolumn{5}{|l|}{ First trimester } \\
\hline Free $\mathrm{T}_{4}(\mathrm{ng} / \mathrm{dl})$ & 557 & 0.76 & 0.82 & 0.89 \\
\hline $\mathrm{TSH}(\mathrm{mU} / \mathrm{l})$ & 557 & 0.80 & 1.18 & 1.75 \\
\hline Urine iodine $(\mu \mathrm{g} / \mathrm{l})$ & 251 & 56 & 95 & 154 \\
\hline \multicolumn{5}{|l|}{ Third trimester } \\
\hline Urine iodine $(\mu \mathrm{g} / \mathrm{l})$ & 528 & 64 & 104 & 161 \\
\hline
\end{tabular}

age at delivery. Models were also repeated using the SGA variable strictly defined with the Spanish reference tables from Carrascosa (16), thus including those six children excluded in the adjusted SGA variable. TSH showed a non-normal distribution and was logtransformed to study the relationship between the different categories of UIC at the first trimester and TSH. Statistical significance was set at a $p$-value $<0.05$. All analyses were conducted with the STATA 8.2 statistical software package.

\section{Results}

Median UIC in the population studied was 95 and $104 \mu \mathrm{g} / \mathrm{l}$ during the first and third trimesters respectively (Table 1).

UIC both at the first and third trimesters was available in 243 mother-newborn pairs. A statistically significant association was observed between UIC in the first and third trimesters as continuous variables (Spearman correlation: $0.24, p$-value $<0.001$ ), although only $25 \%$ $(n=61)$ of the women with UIC at the first and third trimesters available were in the same category of UIC in both trimesters (Table 2). About $48 \%$ of women $(n=117)$ increased their UIC category and $27 \%$ decreased their UIC category $(n=65)$ between the first and third trimesters. Ten women with UIC below $50 \mu \mathrm{g} / \mathrm{l}$ remained low in the third trimester.

The mean birth weight and height were $3259 \mathrm{~g}$ and $49 \mathrm{~cm}$ respectively. Fifty-one percent of the children included were males (Table 3). After excluding those children who were born before 34 weeks of gestation, there were still 13 newborns with less than 37 weeks of gestation, also considered to be preterm. The mean age, weight, and height of pregnant women were 31 years, $62.3 \mathrm{~kg}$, and $163 \mathrm{~cm}$ respectively. Sixteen percent of the women smoked during pregnancy, and 57\% were nulliparous. About 10 and $11 \%$ of the women used iodized salt at the first and third trimesters respectively. About 6 and $8.6 \%$ of women used iodine supplements during the first and third trimesters of pregnancy, either as iodine or multivitamin tablets containing between 100 and $200 \mu \mathrm{g}$ of iodine each.

Six percent of infants were classified as SGA. When infants were categorized according to UIC levels during pregnancy, the lowest rates of SGA were observed among those whose mothers had UICs between 100 and $149 \mu \mathrm{g} / \mathrm{l}$ either in the first or third trimester, as well as among those with UICs above $249 \mu \mathrm{g} / \mathrm{l}$ in the first trimester (Table 4). The highest rate of SGA was observed in children whose mothers had UICs below $50 \mu \mathrm{g} / \mathrm{l}$ in the third trimester $(10 \%)$. Small differences in median birth weight were seen among groups, with the highest median birth weight observed among infants whose mothers had UICs between 100 and $149 \mu \mathrm{g} / \mathrm{l}$ in either the first or third trimester.

In the multivariate model, women with UICs between 100 and $149 \mu \mathrm{g} / \mathrm{l}$ in the third trimester had the lowest risk of having an SGA infant, and their babies had higher mean birth weights than those with UICs below $50 \mu \mathrm{g} / \mathrm{l}$ (Table 5). Birth weights among women with UICs between 50 and $99 \mu \mathrm{g} / \mathrm{l}$ in the third trimester were also significantly higher than those among women with UICs below $50 \mu \mathrm{g} / \mathrm{l}$. However, for women with UICs in categories above $150 \mu \mathrm{g} / \mathrm{l}$, the increase in adjusted mean birth weight and the reduced probability of having an SGA infant did not reach significance. UICs at the first trimester showed similar findings than UICs at the third trimester, particularly for birth weight, although differences were not statistically significant. Free $\mathrm{T}_{4}$ and TSH measured during the first trimester were not associated with birth weight. When models were repeated using the classical SGA outcome, a decreased risk of having a small baby was again observed only in those women with UICs between 100 and $149 \mu \mathrm{g} / \mathrm{l}(\mathrm{OR}(95 \% \mathrm{CI}): 0.27(0.08-0.98))$ at the third trimester. Associations between thyroid function and UICs at the first and third trimesters did not change after excluding those children classified as LGA (data not shown).

Table 2 Distribution of pregnant women according to the urinary iodine concentrations (UIC) at the first and third trimesters ( $n$ (\%)).

\begin{tabular}{llllll}
\hline & \multicolumn{5}{c}{ UIC (third trimester) } \\
\cline { 2 - 6 } & $<50 \mu \mathrm{g} / \mathrm{l}$ & $50-99 \mu \mathrm{g} / \mathrm{l}$ & $100-149 \mu \mathrm{g} / \mathrm{l}$ & $150-249 \mu \mathrm{g} / \mathrm{l}$ & $>249 \mu \mathrm{g} / \mathrm{l}$ \\
\hline UIC (first trimester) & & & & & \\
$<50 \mu \mathrm{g} / \mathrm{l}$ & $10(20)$ & $18(36)$ & $10(20)$ & $17(22)$ & $3(6)$ \\
$50-99 \mu \mathrm{g} / \mathrm{l}$ & $8(10)$ & $22(28)$ & $22(29)$ & $15(31)$ & $8(10)$ \\
$100-149 \mu \mathrm{g} / \mathrm{l}$ & $4(8)$ & $14(29)$ & $10(20)$ & $15(31)$ & $6(12)$ \\
$150-249 \mu \mathrm{g} / \mathrm{l}$ & $0(0)$ & $6(21)$ & $6(30)$ & $3(15)$ & $4(19)$ \\
$>249 \mu \mathrm{g} / \mathrm{l}$ & $1(5)$ & $6(30)$ & & & $4(20)$ \\
\hline
\end{tabular}


Table 3 Characteristics of the study population.

\begin{tabular}{|c|c|c|}
\hline \multicolumn{3}{|l|}{ Newborn variables $(n=557)$} \\
\hline \multirow{2}{*}{\multicolumn{2}{|c|}{$\begin{array}{l}\text { Sex }(\% \text { males }) \\
\text { Gestational age }^{a} \text { (weeks) }\end{array}$}} & $50.81 \%$ \\
\hline & & $40(1.4)$ \\
\hline \multicolumn{2}{|l|}{ Premature ( $\%<37$ weeks) } & $3.2 \%$ \\
\hline \multicolumn{2}{|l|}{ Birth weight ${ }^{\mathrm{a}}(\mathrm{g})$} & $3259(420)$ \\
\hline \multirow{2}{*}{\multicolumn{3}{|c|}{$\begin{array}{l}\text { Birth height }{ }^{\mathrm{a}}(\mathrm{cm}) \\
\text { Maternal variables }(n=557)\end{array}$}} \\
\hline \multirow{2}{*}{\multicolumn{2}{|c|}{$\begin{array}{l}\text { Maternal variables }(n=557) \\
\text { Age }^{\mathrm{a}} \text { (weeks) }\end{array}$}} & \\
\hline & & $31(4.3)$ \\
\hline \multicolumn{2}{|l|}{ Weight $^{\mathrm{a}}(\mathrm{g})$} & $62.3(11.8)$ \\
\hline \multicolumn{2}{|l|}{ Height $^{\mathrm{a}}(\mathrm{cm})$} & $163(6)$ \\
\hline \multicolumn{2}{|l|}{ Race (\% white) } & $97 \%$ \\
\hline \multirow{2}{*}{\multicolumn{3}{|c|}{$\begin{array}{l}\text { Smoking during pregnancy (\% yes) } \\
\text { Studies (\%) }\end{array}$}} \\
\hline & & \\
\hline \multirow{2}{*}{\multicolumn{2}{|c|}{$\begin{array}{l}\text { Primary or less than primary } \\
\text { Secondary }\end{array}$}} & $28 \%$ \\
\hline & & $43 \%$ \\
\hline \multicolumn{2}{|l|}{ High } & $29 \%$ \\
\hline \multicolumn{2}{|l|}{ Nullipara (\%) } & $57 \%$ \\
\hline $\begin{array}{l}\text { Characteristics at } \\
\text { sampling }\end{array}$ & $\begin{array}{l}\text { First trimester } \\
\quad(n=251)\end{array}$ & $\begin{array}{l}\text { Third trimester } \\
\quad(n=528)\end{array}$ \\
\hline Gestational age $^{\mathrm{a}}$ (weeks) & $13(1.7)$ & $34(1.4)$ \\
\hline \multicolumn{3}{|l|}{ Time $(\%)$} \\
\hline Before $1000 \mathrm{~h}$ & $31 \%$ & $31 \%$ \\
\hline $1000-1200 \mathrm{~h}$ & $44 \%$ & $51 \%$ \\
\hline $1200-1400 \mathrm{~h}$ & $6 \%$ & $13 \%$ \\
\hline After $1400 \mathrm{~h}$ & $19 \%$ & $6 \%$ \\
\hline \multicolumn{3}{|l|}{ Station (\%) } \\
\hline Winter & $22 \%$ & $27 \%$ \\
\hline Spring & $23 \%$ & $25 \%$ \\
\hline Summer & $27 \%$ & $25 \%$ \\
\hline Autumn & $28 \%$ & $23 \%$ \\
\hline Use of iodized salt & $10 \%$ & $11 \%$ \\
\hline Iodine supplementation (\%) & $6.4 \%$ & $8.6 \%$ \\
\hline
\end{tabular}

${ }^{\mathrm{a}}$ Characteristic described as mean (s.D.)

Associations observed between UIC and SGAadj/ birth weight were similar when models were repeated in the subset of women who had all the measurements available (free $\mathrm{T}_{4}$, TSH, and UICs at the first and third trimesters; Table 6). However, high TSH levels become statistically significantly related to an increase in the risk of having a small baby and lower birth weight. Moreover, the odds ratio for the category of women with UIC between 100 and $149 \mu \mathrm{g} / \mathrm{l}$ was not statistically significant, although this category had again the lowest odds ratio in both the trimesters.

The adjusted association between $\mathrm{TSH}$ and $\mathrm{T}_{4}$ and the different categories of UIC (first trimester) is shown in Table 7. A linear relationship is not observed between the different categories of UIC and $\mathrm{TSH}$ or $\mathrm{T}_{4}$; however, those women with UIC between 100 and $149 \mu \mathrm{g} / \mathrm{l}$ had lower levels of TSH (adjusted coefficient: $-0.36(0.15)$ $\mathrm{mU} / \mathrm{l} \log$-TSH) and higher levels of $\mathrm{T}_{4}$ (adjusted coefficient (s.E.M.): $0.05(0.02) \mathrm{ng} / \mathrm{dl})$ than those with the UIC below $50 \mu \mathrm{g} / \mathrm{l}$. Moreover, those women with UIC between 50 and $99 \mu \mathrm{g} / \mathrm{l}$ had also higher levels of $\mathrm{T}_{4}$ than those women from the reference category. Among the other UIC categories, there were no differences on free $\mathrm{T}_{4}$ and $\mathrm{TSH}$.

\section{Discussion}

We observed that healthy pregnant women with the third trimester UICs below $50 \mu \mathrm{g} / \mathrm{l}$ were significantly more likely to have an SGA infant than women with the UICs between 100 and $149 \mu \mathrm{g} / \mathrm{l}$ and their infants had a lower mean birth weight than women with the UIC between 50 and $149 \mu \mathrm{g} / \mathrm{l}$. A similar pattern was seen for UIC at the first trimester, although differences were not statistically significant. Higher TSH levels were also associated with a higher risk of having an SGA baby or having a newborn with a lower birth weight; nonetheless, this association was observed only when women with all the measurements were analyzed.

The best-established association between THs, iodine, and anthropometric measures is in school and preschool children, generally from iodine-deficient areas where retarded growth has been observed $(15,19)$. Thyroid hormone plays a key role in growth and bone development either indirectly by increasing the secretion of $\mathrm{GH}$ and insulin-like growth factor 1 , or directly by influencing target genes via specific nuclear receptors $(20,21)$. It is well known that the disruption of the hypothalamic-pituitary-thyroid axis during growth profoundly influences skeletal development (22). The expression of $\mathrm{TH}$ receptors in bone cells as

Table 4 Percentage of small for gestational age (adjusted SGA) infants and median interquartile range birth weight according to free thyroxine $\left(\mathrm{fT}_{4}\right)$, thyrotropin (TSH), iodine supplementation, and urinary iodine concentrations (UIC) in pregnant women.

\begin{tabular}{|c|c|c|c|}
\hline & $n$ & SGAadj (\%) & $\begin{array}{l}\text { Birth weight } \\
\text { median (IQR) }\end{array}$ \\
\hline All population & 557 & 6.0 & $3290(2980-3520)$ \\
\hline \multicolumn{4}{|l|}{ First trimester } \\
\hline \multicolumn{4}{|l|}{ Free $T_{4}$} \\
\hline$>\mathrm{PC} 10$ & 501 & 6.2 & 3290 (2990-2010) \\
\hline$<$ PC10 & 56 & 3.6 & $3350(3035-3580)$ \\
\hline \multicolumn{4}{|l|}{ TSH } \\
\hline$<$ PC90 & 501 & 5.8 & 3300 (3000-3520) \\
\hline$>$ PC90 & 56 & 7.0 & $3185(2860-3500)$ \\
\hline \multicolumn{4}{|l|}{ UIC } \\
\hline $\mathrm{UIC}<50 \mu \mathrm{g} / \mathrm{l}$ & 50 & 4.0 & $3257(2960-3500)$ \\
\hline UIC 50-99 $\mu \mathrm{g} / \mathrm{l}$ & 82 & 6.1 & $3312(3020-3640)$ \\
\hline UIC $100-149 \mu \mathrm{g} / \mathrm{l}$ & 50 & 2.0 & 3375 (3060-3530) \\
\hline UIC $150-249 \mu \mathrm{g} / \mathrm{l}$ & 49 & 6.1 & $3300(3080-3510)$ \\
\hline UIC $>249 \mu \mathrm{g} / \mathrm{l}$ & 20 & 0.0 & 3350 (2980-3460) \\
\hline \multicolumn{4}{|c|}{ lodine supplementation } \\
\hline No & 523 & 6.3 & 3290 (2990-3520) \\
\hline Yes & 34 & 0.0 & $3285(2980-3515)$ \\
\hline Third trimester & & & \\
\hline UIC & & & \\
\hline $\mathrm{UIC}<50 \mu \mathrm{g} / \mathrm{l}$ & 70 & 10.0 & $3162(2820-3430)^{*}$ \\
\hline UIC 50-99 $\mu \mathrm{g} / \mathrm{l}$ & 182 & 6.0 & 3300 (2990-3550) \\
\hline UIC $100-149 \mu \mathrm{g} / \mathrm{l}$ & 126 & 1.6 & $3350(3010-3620)$ \\
\hline UIC 150-249 $\mu \mathrm{g} / \mathrm{I}$ & 101 & 5.9 & 3290 (3030-3460) \\
\hline UIC $>249 \mu \mathrm{g} / \mathrm{l}$ & 49 & 8.2 & $3280(3015-3630)$ \\
\hline \multicolumn{4}{|c|}{ lodine supplementation } \\
\hline No & 510 & 6.5 & $3285(2980-3515)$ \\
\hline Yes & 47 & 0.0 & $3370(3080-3645)^{*}$ \\
\hline
\end{tabular}

${ }^{*} P<0.05\left(\chi^{2}\right.$, Mann-Whitney and ANOVA tests).

aQQE: interquartile range. 
Table 5 Adjusted association between urinary iodine concentration, thyrotropin (TSH), thyroxine $\left(\mathrm{T}_{4}\right)$, and fetal weight, using the fetal weight as a dichotomous outcome (small for gestational age (SGA)) and as a continuous variable.

\begin{tabular}{|c|c|c|}
\hline & $\begin{array}{c}\text { Small for gesta- } \\
\text { tional age (SGAadj) } \\
\text { Adjusted odds ratio } \\
(95 \% \mathrm{Cl})\end{array}$ & $\begin{array}{l}\text { Birth weight }(\mathrm{g}) \\
\text { Adjusted } \\
\text { coefficient (S.E.M.) }\end{array}$ \\
\hline \multicolumn{3}{|l|}{ First trimester } \\
\hline Free $\mathrm{T}_{4}(<\mathrm{PC} 10)$ & $0.58(0.13-2.67)$ & $67(54)$ \\
\hline $\begin{array}{l}\text { TSH }(>\text { PC90) } \\
\text { UIC }\end{array}$ & $1.31(0.41-4.17)$ & $-19(52)$ \\
\hline UIC < $50 \mu \mathrm{g} / \mathrm{l}$ & 1 & $3457(113)$ \\
\hline (Reference) & & \\
\hline UIC 50-99 $\mu \mathrm{g} / \mathrm{l}$ & $1.73(0.24-12.56)$ & $123(69)$ \\
\hline UIC $100-149 \mu \mathrm{g} / \mathrm{l}$ & $0.37(0.03-5.36)$ & $133(76)$ \\
\hline UIC $150-249 \mu \mathrm{g} / \mathrm{l}$ & $1.34(0.16-12.06)$ & $78(76)$ \\
\hline UIC $>249 \mu \mathrm{g} / \mathrm{l}$ & Not measurable ${ }^{c}$ & $142(102)$ \\
\hline \multicolumn{3}{|l|}{ Third trimester } \\
\hline $\begin{array}{l}\text { UIC }<50 \mu \mathrm{g} / \mathrm{l} \\
\text { (Reference) }\end{array}$ & 1 & $3506(207)$ \\
\hline UIC 50-99 $\mu \mathrm{g} / \mathrm{l}$ & $0.59(0.21-1.69)$ & $117(51)^{*}$ \\
\hline UIC $100-149 \mu \mathrm{g} / \mathrm{l}$ & $0.15(0.03-0.76)^{\star}$ & $189(54)^{\dagger}$ \\
\hline 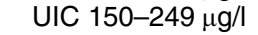 & $0.37(0.10-1.40)$ & $106(57)$ \\
\hline UIC $>249 \mu \mathrm{g} / \mathrm{l}$ & $0.71(0.19-2.75)$ & $99(67)$ \\
\hline
\end{tabular}

${ }^{*} P$ value $<0.05,{ }^{\dagger} P$ value $<0.001$

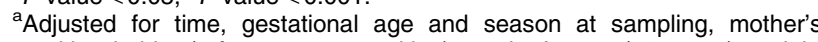
smoking habits (reference: no smoking), mother's age (31 years), weight (63 kg) and height (163 cm), sex (male), and nulliparity (nulliparous).

${ }^{\mathrm{b}}$ Adjusted for gestational age at delivery (40 weeks).

${ }^{\mathrm{C}} \mathrm{OR}$ not measurable (this category of UIC predicts failure perfectly).

the responsiveness to TH in cell culturing systems is the evidence of an effect of $\mathrm{TH}$ on bone tissue (21-23). However, the importance of $\mathrm{TH}$ during the prenatal development is uncertain $(15,23)$ and a very few studies have assessed the role of iodine on prenatal growth $(14,15)$. A recent study in animals showed that hypothyroidism in pregnant mice impaired fetal bone development, but only at the end of fetal life (23). In the present study, the UIC levels during the third trimester of pregnancy were related to birth weight. Nonetheless, no statistically significant relationship was observed for the first trimester UICs and TH.

By convention, standard reference ranges for adults are used during pregnancy, although Hallowell et al. proposed a TSH upper limit of $2.5 \mathrm{mU} / \mathrm{l}$ as a conservative upper guide for the first trimester pregnancy screening. (24). In the present study, we did not observe any adverse effect of high TSH (TSH $>$ $2.42 \mathrm{mU} / \mathrm{l}$ ) or low free $\mathrm{T}_{4}$ concentrations (free $\mathrm{T}_{4}<$ $0.70 \mathrm{ng} / \mathrm{dl}$ ) on birth weight when all women were considered. Nevertheless, when only women with all the measurements available were analyzed, we observed that high TSH levels were related to a higher risk of SGA and lower birth weight. It is known that UI concentration does not always provide direct information about thyroid function $(25,26)$; however, we also found that women whose UICs were within 100 and $149 \mu \mathrm{g} / \mathrm{l}$ during the first trimester also had lower levels of TSH and higher levels of free $\mathrm{T}_{4}$ than women with UIC below
$50 \mu \mathrm{g} / \mathrm{l}$. This pattern was not observed in women with higher UIC levels.

UIC is presently the most practical biomarker for assessing iodine nutrition in a population, although not in individuals since it reflects recent iodine intake (27). Nevertheless, low UI levels probably reflect a prolonged low iodine status in an individual (26). Three methods have been used to estimate daily iodine requirements in adults: 1) iodine turnover, 2) iodine balance, and 3) UI concentration and thyroid size (28). The iodine requirements during pregnancy increase since there is an increment in TH synthesis to provide for the needs of the fetus, and there is an increased loss of iodine in the urine resulting from an increased renal clearance during pregnancy $(2,28,29)$. The recommended iodine intake in pregnant women, at the moment $250 \mu \mathrm{g}$ per day, has been mainly extrapolated from the nonpregnant adult estimations (for whom the recommended level is $150 \mu \mathrm{g} /$ day), and it is thus essentially based on theoretical considerations (18, 29). Given the increased needs and elevated excretion rates, there is a need to empirically validate the recommended median UI in pregnant women in relation to the consequences for reproductive outcomes as well as longer term outcomes such as child development, maternal goiter, or thyroid autoimmunity. Moreover, it is important to clarify whether an increase in iodine intake is required among pregnant women

Table 6 Adjusted association between urinary iodine concentration, thyrotropin (TSH), thyroxine $\left(\mathrm{T}_{4}\right)$, and fetal weight, using the fetal weight as a categorical outcome (small for gestational age) and as a dichotomous variable. Only women with all measurements available were included $(n=239)$.

\begin{tabular}{cll}
\hline & $\begin{array}{c}\text { Small for gesta- } \\
\text { tional age (SGAadj) } \\
\text { Adjusted } \text { odds ratio }^{\text {(95\% Cl) }}\end{array}$ & $\begin{array}{c}\text { Birth weight (g) } \\
\text { Adjusted }\end{array}$ \\
coefficient (s.E.M.)
\end{tabular}

${ }^{*} P$ value $<0.05$

${ }^{a}$ Adjusted for time, gestational age and season at sampling, mother's smoking habits (reference: no smoking), mother's age (31 years), weight $(63 \mathrm{Kg})$ and height $(163 \mathrm{~cm})$, sex (male), and nulliparity (nulliparous). ${ }^{\mathrm{b}}$ Adjusted for gestational age at delivery (40 weeks).

${ }^{\mathrm{c} O R}$ not measurable (this category of UIC predicts failure perfectly). 
Table 7 Adjusted ${ }^{a}$ association between thyroxine $\left(T_{4}\right)$, thyrotropin, and urinary iodine concentrations (UIC) at the first trimester $(n=251)$.

\begin{tabular}{llll}
\hline & & \multicolumn{2}{c}{ Adjusted $^{\mathrm{a}}$ coefficient (S.E.M.) $^{2}$} \\
\cline { 3 - 4 } & $\boldsymbol{n}$ & $\mathrm{TSH}^{\mathrm{b}}(\mathrm{mU} / \mathrm{l})$ & $\mathrm{T}_{4}(\mathrm{ng} / \mathrm{dl})$ \\
\hline UIC (first trimester) & & & \\
UIC $<50 \mu \mathrm{g} / \mathrm{l}$ & 50 & Reference & Reference \\
UIC $50-99 \mu \mathrm{g} / \mathrm{l}$ & 82 & $-0.07(0.14)$ & $0.05(0.02)^{\dagger}$ \\
UIC $100-149 \mu \mathrm{g} / \mathrm{l}$ & 50 & $-0.36(0.15)^{\star}$ & $0.05(0.02)$ \\
UIC $150-249 \mu \mathrm{g} / \mathrm{l}$ & 49 & $-0.16(0.15)$ & $0.02(0.02)$ \\
UIC $>249 \mu \mathrm{g} / \mathrm{l}$ & 20 & $-0.09(0.21)$ & $0.00(0.03)$ \\
\hline
\end{tabular}

${ }^{\dagger} P$ value $<0.01,{ }^{*} P$ value $<0.05$

adjusted for mother's weight and age, gestational age at sampling, and mother's smoking habits.

${ }^{\mathrm{b}} \mathrm{TSH}$ was log-transformed to normalize the distribution.

from iodine-sufficient areas, since physiological adaptations in iodine metabolism take place among women with adequate iodine intake before pregnancy (30). It is possible that recommending an increase in iodine intake during pregnancy may be excessive in these populations.

Iodine status in the pregnant women of the present study would be considered inadequate based on the present WHO criteria (18). Some parts of Spain have had historical problems of endemic goiter described during the 1970s and 1980s; however, the situation improved after information campaigns for eradicating iodine deficiency (31).

The major disadvantage of the present study is the use of UIC as an indicator of individual iodine status, although a categorization in five different groups according to UIC instead of using the continuous measure diminishes the possible misclassification bias due to daily variations of iodine intake. Unfortunately, not all pregnant women had UICs analyzed at both trimesters because of budget restrictions, thus separate analyses were done for each trimester, and a decreased risk of SGA was observed in women with UICs between 100 and $149 \mu \mathrm{g} / \mathrm{l}$ during either the first or third trimester (although only statistically significant at the third trimester), which reinforces the association. Moreover, there is likelihood that women with higher UIC had also a higher daily intake of energy or of other nutrients beneficial for fetal growth, although the effect of UIC did not change after the adjustment for total calories intake. Other disadvantages were the missing information on the prevalence of positive TPOAb in the present population and on thyroxin binding globulin (TBG) concentrations to calculate the free $\mathrm{T}_{4} / \mathrm{TBG}$ ratio. Thyroid autoimmunity, which is the most common cause of subclinical hypothyroidism in iodine-sufficient areas, influences TSH levels and also plays a critical role in pregnancy outcome (32). Moreover, some $\mathrm{TH}$ variations observed during pregnancy (for instance, a decrease of free $\mathrm{T}_{4}$ levels) are the direct consequence of an increase in serum TBG (33). Multivariate models were adjusted for gestational age at sampling to reduce the possible bias due to variations during gestation.

In conclusion, we have observed an association between thyroid function, iodine status, and prenatal growth. This study suggests a beneficial effect on birth weight at UIC below the present recommendations. Further studies should be undertaken to assess the effects of moderate-to-mild iodine deficiency and iodine excess during pregnancy, as well as to validate the present guidelines in relation to reproductive and longterm outcomes in both iodine-deficient and -sufficient areas.

\section{Declaration of interest}

The authors declare that there is no conflict of interest that could be perceived as prejudicing the impartiality of the research reported.

\section{Funding}

This study was funded by grants from the Spanish Ministry of Health (FIS-FIS-PI041436), Instituto de Salud Carlos III (Red INMA G03/176 and CBO6/02/0041), and the Generalitat de Catalunya-CIRIT 1999SGR 00241.

\section{Acknowledgements}

We are grateful to Silvia Fochs, Anna Sànchez, Maribel López, and Nuria Pey for their assistance in contacting the families and administering the questionnaires.

\section{References}

1 de Escobar GM, Obregon MJ \& del Rey FE. Maternal thyroid hormones early in pregnancy and fetal brain development. Best Practice and Research. Clinical Endocrinology and Metabolism 2004 18 225-248.

2 Glinoer D. The regulation of thyroid function during normal pregnancy: importance of the iodine nutrition status. Best Practice and Research. Clinical Endocrinology and Metabolism 200418 133-152.

3 Pharoah PO, Buttfield IH \& Hetzel BS. Neurological damage to the fetus resulting from severe iodine deficiency during pregnancy. Lancet 19711 308-310.

4 Haddow JE, Palomaki GE, Allan WC, Williams JR, Knight GJ, Gagnon J, O'Heir CE, Mitchell ML, Hermos RJ, Waisbren SE, Faix JD \& Klein RZ. Maternal thyroid deficiency during pregnancy and subsequent neuropsychological development of the child. New England Journal of Medicine 1999 341 549-555.

5 Delange F. Iodine deficiency as a cause of brain damage. Postgraduate Medical Journal 200177 217-220.

6 Leung AS, Millar LK, Koonings PP, Montoro M \& Mestman JH. Perinatal outcome in hypothyroid pregnancies. Obstetrics and Gynecology 199381 349-353.

7 Casey BM, Dashe JS, Wells E, McIntire DD, Byrd W, Leveno KJ \& Cunningham FG. Subclinical hypothyroidism and pregnancy outcomes. Obstetrics and Gynecology 2005105 239-245.

8 Abalovivh M, Gutierrez S, Alcaraz G, Maccallini G, Garcia A \& Levalle O. Overt and subclinical hypothyroidism complicating pregnancy. Thyroid $20021263-67$.

9 Das SC, Mohammed AZ, Al-Hassan S, Otokwula AA \& Isichei UP. Effect of environmental iodine deficiency (EID) on fetal growth in Nigeria. Indian Journal of Medical Research $2006 \mathbf{1 2 4} 535-544$. 
10 Allan WC, Haddow JE, Palomaki GE, Williams JR, Michell ML, Hermos RJ, Faix JD \& Klein RZ. Maternal thyroid deficiency and pregnancy complications for population screening. Journal of Medical Screening 20007 127-130.

11 Matalon S, Sheiner E, Levy A, Mazor M \& Wiznitzer A. Relationship of treated maternal hypothyroidism and perinatal outcome. Journal of Reproductive Medicine 200651 59-63.

12 Blazer S, Moreh-Waterman Y, Miller-Lotan R, Tamir A \& Hochberg Z. Maternal hypothyroidism may affect fetal growth and neonatal thyroid function. Obstetrics and Gynecology 2003 $102232-241$.

13 Cleary-Goldman J, Malone FD, Lambert-Messerlian G, Sullivan L, Canick J, Porter TF, Luthy D, Gross S, Bianchi DW, D'Alton ME \& for the FASTER Consortium. Maternal thyroid hypofunction and pregnancy outcome. Obstetrics and Gynecology 2008112 85-92.

14 Chaouki ML \& Benmiloud M. Prevention of iodine deficiency disorders by oral administration of lipiodol during pregnancy. European Journal of Endocrinology 1994130 547-551.

15 Mason JB, Deitchler M, Gilman A, Gillenwater K, Shuaib M, Hotchkiss D, Mason K, Mock $\mathrm{N}$ \& Sethuraman K. Iodine fortification is related to increased weight-for-age and birthweight in children in Asia. Food and Nutrition Bulletin 20023 292-308.

16 Carrascosa A, Yeste D, Copil A, Almar J, Salcedo S \& Gussinyé M. Anthropometric growth patterns of preterm and full-term newborns (24-42 weeks gestational age) at the Hospital MaternoInfantil Vall d'Hebron (Barcelona) (1997-2002). Anales de Pediatría $200460406-416$ (Spanish).

17 Mamelle N, Cochet V \& Claris O. Definition of fetal growth restriction according to constitutional growth potential. Biology of the Neonate $200180277-285$.

18 Andersson M, de Benoist B, Delange F \& Zupan J. WHO Secretariat on behalf of the participants to the consulation. Prevention and control of iodine deficiency in pregnant and lactating women and in children 2-years-old: conclusions and recommendations of the Technical Consulation. Public Health Nutrition 200710 1606-1611.

19 Koutras DA, Christakis G, Trichopoulous D, Dakou-Voutetaki A, Kyriakopoulous V, Fontanares P, Livadas DP, Gatsios D \& Malamos B. Endemic goiter in Greece: nutritional status, growth, and skeletal development of goitrous and nongoitrous populations. American Journal of Clinical Nutrition 197326 1360-1368.

20 Rivkees SA, Bode HH \& Crawford JD. Long-term growth in juvenile acquired hypothyroidism: the failure to achieve normal adult stature. New England Journal of Medicine 1988318 599-602.
21 Abu EO, Bord S, Horner A, Chatterjee VK \& Compston JE. The expression of thyroid hormone receptors in human bone. Bone 199721 137-142.

22 Bassett JH \& Williams GR. Critical role of the hypothalamicpituitary-thyroid axis in bone. Bone $2008 \mathbf{4 3} 418-426$.

23 Capelo LP, Beber EH, Huang SA, Zorn TM, Bianco AC \& Gouveia $\mathrm{CH}$. Deiodinase-mediated thyroid hormone inactivation minimizes thyroid hormone signaling in the early development of fetal skeleton. Bone 200843 921-930.

24 Hallowell JG, LaFranchi S, Smallridge RC, Spong CY, Hadoww JE \& Boyle C. 2004 Where do we go from here? - summary of working group discussions on thyroid function and gestational outcomes Thyroid $20051572-76$.

25 Hallowell JG \& Haddow JE. The prevalence of iodine deficiency in women of reproductive age in United States of America. Public Health Nutrition 200710 1532-1539.

26 Soldin OP, Rochelle E, Tractenberg RE \& Pezzullo JC. Do thyroxine and thyroid-stimulating hormone levels reflect urinary iodine concentrations? Therapeutic Drug Monitoring 200527 178-185.

27 WHO, UNICEF, and ICCIDD. Assessment of the Iodine Deficiency Disorders and Monitoring Their Elimination. A Guide for Programme Managers. (WHO/NHD/01.1). 2 edn. Geneva: World Health Organization, 2001.

28 Zimmermann MB. The impact of iodised salt or iodine supplements on iodine status during pregnancy, lactation and infancy. Public Health Nutrition 200710 1584-1595.

29 Delange F. Iodine requirements during pregnancy, lactation and the neonatal period and indicators of optimal iodine nutrition. Public Health Nutrition 200710 1571-1580.

30 Glinoer D. The importance of iodine nutrition during pregnancy. Public Health Nutrition 200710 1542-1546.

31 Díaz-Cadorniga FJ \& Delgado-Alvarez E. Déficit de yodo en España (Situación actual). Endocrinología y Nutrición 2004 1 2-13 (Spanish).

32 Wier FA \& Farley CL. Clinical controversies in screening women for thyroid disorders during pregnancy. Journal of Midwifery and Women's Health $2006 \mathbf{5 1} 152-158$.

33 Glinoer D. The regulation of thyroid function in pregnancy: pathways of endocrine adaptation from physiology to pathology. Endocrine Reviews 199718 404-433.

Received 5 December 2008

Accepted 29 December 2008 